\title{
Balancing Text and Context through Maqasid-Based ljtihad
}

\author{
Tengku Ahmad Hazri*
}

Contemporary ijtihad is faced with the challenge of relating the revealed text to the surrounding circumstances, i.e. the "text" to the "context" as Tariq Ramadan puts it. This is perhaps why ijtihad is often seen as the principal instrument by which reason is negotiated with revelation. But there may be instances where an asymmetry exists between the text and the context. In such scenarios, one remedy which has been proposed is for the text to be made adapted to the context. However, the context itself may sometimes be interpreted, understood and conceptualised within a framework that may be at odds with the objectives of Shari'ah (maqasid al-shariah). Maqasid-based ijtihad offers a possible way of converging, synthesising and harmonising the context and the text.

One overriding theme of maqasid al-shari'ah is that maqasid should enlighten the path of usul al-fiqh (legal methodology) for the usul has become burdened with technicalities. Through the retrieval of the underlying objectives of the Shariah it is hoped that such difficulties can be overcome. Yet a historical look at the development of Islamic law reveals the centrality of ijtihad. We know this by looking at the very hadith which establishes the proof or authority for ijtihad, namely, the hadith of Mu'adh ibn Jabal, in which Mu'adh said, on being asked by the Prophet (pbuh) how he would decide cases that come before him, that he would refer, first to the Qur'an, then the Sunnah of the Prophet, and then he would exert himself (ajtahidu) — saying nothing about of the various methods that we find in usul al-fiqh. These evolved later as variations and formalisations of ijtihad within procedural restrictions. It follows therefore, that the placing of maqasid-based ijtihad at the forefront of Islamic legal thought is none other than restoration of the original spirit of the Shari'ah.

Indeed knowledge of the maqasid is one of the requirements or conditions of a mujtahid. Ibrahim al-Shatibi was even explicit about it by classifying ijtihad into two headings, namely, those of the purposes and those of the sources and methods of deduction. The former is more fundamental than the latter and in fact, the latter serve the former. Earlier scholars have also hinted at the same idea, for instance, al-Shafi'i (as later quoted al-Ghazali and al-Shawkani) claimed that universal principles should be given priority over particulars. And thus, there 
has always been recognition of knowledge of the maqasid as a prerequisite or requirement for ijtihad.

But the differences between maqasid and ijtihad must also be noted. Maqasid are basically abstract, general principles, not the specific rulings themselves. Thus, faced with specific issues demanding practical and pragmatic rules to guide action, laying down the maqasid per se would be insufficient. Instead, specific conclusions are needed so as to enable the maqasid to resolve the pressing issue or problem that the jurist is confronted with.

Ijtihad by contrast is practical, as can be discerned from its very definition, namely as "the total expenditure of effort by a jurist to infer with a degree of probability, the rules of Shari'ah from the detailed evidence in the sources". ${ }^{1}$ And thus, whereas the maqasid are abstract, theoretical and conceptual, ijtihad is practical and result-oriented, and thus capable of operationalising the maqasid or putting them in practice.

From this definition it follows that ijtihad is a "legal" exercise. "Maqasidbased ijtihad" is precisely the means by which links can be established between the "legal" and its so-called "context".

\section{II}

The process of ijtihad involves two types of knowledge, namely, knowledge of the law, and knowledge of the circumstances that need legal resolution (i.e. the "context"). What we have considered thus far in relation to the requirements, conditions and prerequisites for ijtihad relate largely to the "legal" dimension of ijtihad. These are knowledge of the Qur'an, knowledge of the Sunnah, knowledge of the Arabic language, knowledge of the branches of law (furu' works) and where there is consensus (ijma'), knowledge of analogical reasoning (qiyas) and knowledge of the purposes of Shariah. The jurist must also be aware of the custom of society. Yet the question remains: what is the conceptual framework needed for such knowledge?

One possible solution to the dilemma which has been advanced is for the coming together of 'ulama al-nusus (scholars of the texts) and 'ulama al-waqi' (scholars of the context). But this approach, apart from being dualistic, assumes the mutual exclusiveness of the "text" and "context". The eminent philosopher Seyyed Hossein Nasr aptly says, "These days we are often told to keep up with the times. Rarely, however, does one ask what the "times' have to keep up with." Nasr's critique underscores an important point about the so-called "context": that the so-called context itself is produced and interpreted in accordance with a particular conceptual framework. It is the interaction of the conscious subject with the world around it that produces what is called the "context". But how can 
the Shari' ah be made to "adapt" to the "context" if the "context" in relation to say, issues in economics, governance, politics and human rights, is itself interpreted in accordance with conceptual framework which rests on mistaken assumptions about the nature of man, his needs and his aspirations?

\section{III}

Let's now return to the two dimensions of revelation. To recapitulate, these are (1) the sacred Law which guides human conduct, and (2) information about the nature of reality. This distinction finds its expression in Ibrahim al-Shatibi's distinction between 'legal intent' (maqasid al-shariah) and 'creational intent' (maqasid al-khalq). It is not the Shari'ah alone that is purposive but the whole of creation itself has been created towards end-goals, or purposes. This is indicated in several verses of the Qur'an, for instance, in Sura Ali Imran (3:115), "Did you think We have created you in play (i.e. without purpose)?"; Sura al-Dukhan (44:38), "And We did not create the heavens and the earth and that between them in play"; and Surah Sad (38:27), "And We did not create the heavens and the earth and that between them aimlessly."

Gamal Eldin Attia builds upon this distinction to elaborate on six different types or categories of maqasid. These are (1) the maqasid of creation (maqasid al-khalq), (2) the higher maqasid of the Law (maqasid al-shari'ah al- 'aliyah), (3) the universal maqasid of the Law (maqasid al-shari'ah al-kulliyyah), (4) special maqasid of the Law (maqasid al-kulliyyah al-khassah), (5) the particular maqasid of the Law (maqasid al-shari'ah al-juz'iyyah), and (6) human maqasid (maqasid al-mukallafin). ${ }^{2}$ To recall from our earlier point, maqasid-based ijtihad is one way of establishing harmony between the Shariah and the so-called "context". Attia's six-fold classification represents an attempt towards that.

\section{IV}

In practical terms, therefore, the harmonisation of legal and creational intents allow for the broader selection of literature from which the maqasid could be ascertained, not strictly from the genre of figh or usul al-figh, but also from theology ('ilm al-kalam), spirituality (tasawwuf), ethics (akhlaq), politics (siyasa) and philosophy (hikmah or falsafah). In the latter literature, there are ample discussions on what Shatibi and Attia called maqasid al-khalq, although these are hardly referred to by this name. Ibn 'Ashur in his Treatise on Maqasid al-Shari'ah argues that the maqasid al-shariah are grounded in fitrah (the innate nature of man). In elaborating on the nature of fitrah, he cites from the philosopher Ibn Sina. In philosophical literature, the realisation of man's fitrah is explained in terms of the acquisition of the four cardinal virtues (al-fada' $i$ ), 
namely temperance ('iffah), courage (shaja'ah), wisdom (hikmah) and justice ('adalah). The one who has attained to these virtues has fulfilled the maqasid al-khalq in relation to the human species and thereby be in conformity with his fitrah, which Ibn "Ashur defined as "the natural disposition (khilqah) and order (nizam) that God has instilled in every created being."

If the categorisation of maqasid is construed hierarchically, from the most pressing, urgent and necessary to the aspirational, the fulfillment of the fitrah amounts to conformity to the highest aspiration of the maqasid for to seek for the refinement and excellence (ihsan) in a thing is none other than to seek for the complete realisation and fulfillment of a thing's reality (haqiqah) as intended by the Creator, including its objective and purpose in the total scheme of things. Such convergence of legal and creational intents is indeed realised in the very person of the Prophet (pbuh), who as concurrently lawgiver (shari') and legally competent addressee of Shari'ah (mukallaf), embodies the harmony of maqasid al-shari'ah and maqasid al-mukallafin (human maqasid), a part of maqasid al$k h a l q$. That it is possible for other than the Prophet to likewise harmonise the two is indicated in the hadith that "when [God] loves [a servant] [He becomes] his hearing with which he hears, his sight with which he sees, his hands with which he seizes and his legs with which he walks." 3

There have also been works which attempt to harmonise the two maqasid. One example is Shah Wali Allah's Hujjat Allah al-Baligha (The Conclusive Argument from God). It is interesting that Shah Wali Allah deemed his work to be a work on the science of asrar al-din (secrets or inner meanings of religion), which is almost the same as Ibn 'Ashur's definition of maqasid al-shari'ah, namely as "the deeper meanings (ma'ani) and inner aspects of wisdom (hikam) considered by the Lawgiver (Shari') in all or most of the areas and circumstances of legislation (ahwal al-tashri')", ${ }^{4}$ with the important difference that, whereas Ibn 'Ashur focuses on the Shariah, Wali Allah probed even into the inner meanings of beliefs and elaborated on the metaphysical realities as informed through revelation. He explained how the whole of created world is made towards serving the universal interest or universal comprehensive benefit (al-maslaha al-kulliyya). In other words, Wali Allah sought to harmonise, synthesise and synergise maqasid alshariah and maqasid al-khalq.

It is in the harmonisation of these two that we find the significant contribution of maqasid-based ijtihad.

\section{Notes}

* Tengku Ahmad Hazri is Research Fellow at IAIS Malaysia. He would like to acknowledge and thank Prof. Mohammad Hashim Kamali, Dr. Daud Batchelor, Dr. Mohammed Farid Ali, Tawfique al-Mubarak and Ahmad Badri Abdullah for 
their constructive arguments and critical insights which have helped to refine the viewpoint from an earlier draft. He may be reached at ahmhazri@iais.org.my.

1. Mohammad Hashim Kamali, Principles of Islamic Jurisprudence (Cambridge: Islamic Texts Society, 2003) (Third Revised and Enlarged Edition), 469.

2. Gamal Eldin Attia, Towards Realization of the Higher Intents of Islamic Law: Maqasid al-Shari'ah - A Functional Approach (translated from the Arabic by Nancy Roberts (Kuala Lumpur: Islamic Book Trust, 2010), 90-115.

3. Narrated by Bukhari.

4. Ibn Ashur, Treatise on Maqasid al-Shari'ah (translated from the Arabic and annotated by Mohamed El-Tahir El-Mesawi) (London and Washington: The International Institute of Islamic Thought (IIIT)), 67. 